\title{
Montane Amphibian and Reptile Communities in Madagascar
}

\author{
CHRISTOPHER J. RAXWORTHY AND RONALD A. NUSSBAUM
}

Museum of Zoology, University of Michigan, Ann Arbor, MI 48109-1079, U.S.A.

\begin{abstract}
Two babitats in Madagascar, secondary, montane beatbland and bigb plateau prairie, are considered artifictal, baving been created by buman-set fires soon after the island was colontzed less than 2000 years ago. These pratrie and secondary beatbland babitats are also thought to be degraded and faunistically depauperate. To test the depauperate fauna bypothesis we measured levels of berpetofaunal (amphibian and reptile) endemicity between primary forest, montane secondary beathland, and bigh plateau prairie. We found no species endemic to bigb plateau pratrie, but a significant percentage of the montane berpetofauna is restricted to post-fire secondary beathland. These results support the buman-origin bypotbesis for prairie, but secondary beatbland appears to be a natural, post-fire successional stage that leads to a climax of sclerophyllous forest. This suggests that careful management of montane beatbland could establish new dispersal corridors between currently isolated montane forest blocks and, therefore, could offer new opportunities for conservation in Madagascar. Despite widespread burning, the montane beatblands of Madagascar bave diverse berpetofaunal communities, demonstrating that these montane communities are not as seriously degraded as previously believed, and that tbey may be naturally resistant to fire.
\end{abstract}

\section{Comunidades de Anfibios y Reptiles de Montaña en Madagascar}

Resumen: En Madagascar los hábitats de brezal secundario de montaña y los de la pradera alta (High Plateau) son considerados como artificiales debido a que se originaron por incendtos provocados por bumanos poco después de la colonización de la isla menos de 2000 años a.C. También se piensa que estos bábitats están degradados y la fauna se encuentra en condictones paupérrimas. Para evaluar la bipotesis de pauperización de la fauna, medimos los niveles de endemismo de la berpetofauna (anfibios y reptiles) entre bosque primario, brezal secundario y la pradera High Plateau. No encontramos especies endémicas a la pradera Higb Plateau, pero un procentaje significativo de la berpetofauna de montaña está restringido a tierras de post-incendio secundario. Estos resultados soportan la bipótesis de origen-bumano para las regiones de pradera, pero los bábttats de brezal secundarios parecen presentar un estado seral natural post-incendio que conducen a un clímax de bosque esclerofilo. Esto sugiere que un manejo cuidadoso de los brezales de montaña puede permitir nuevos corredores de dispersión entre bloques de bosque de montaña actualmente aislados y de esta manera ofrecer nuevas oportunidades de conservación en Madagascar. A pesar de los tan comunes incendios, los brezales de montaña de Madagascar poseen comunidades diversas de berpetofauna que de muestran que estas áreas no se encuentran seriamente degradadas como previamente se babia pensado, además de que pueden presentar resistencia natural al fuego.

\section{Introduction}

The High Plateau of Madagascar (Fig. 1) was once assumed to have been almost completely forested before the arrival of humans (Perrier de la Bâthie 1921; Hum-

Paper submitted February 15, 1995; revised manuscript accepted November 28, 1995.

750

Conservation Biology, Pages 750-756

Volume 10, No. 3, June 1996 bert 1927), but it was actually a dynamic mosaic of heathland, grassland, and forest during the Holocene, 11,000-1240 years ago (MacPhee et al. 1985; Burney $1987 a, 1987 b$ ). The current prairies of the high plateau are believed to be artificial habitats created by clearing, burning, and cattle grazing (Humbert 1927; Koechlin 1972; Dewar 1984). In support of this interpretation, these prairies appear to have an impoverished fauna 


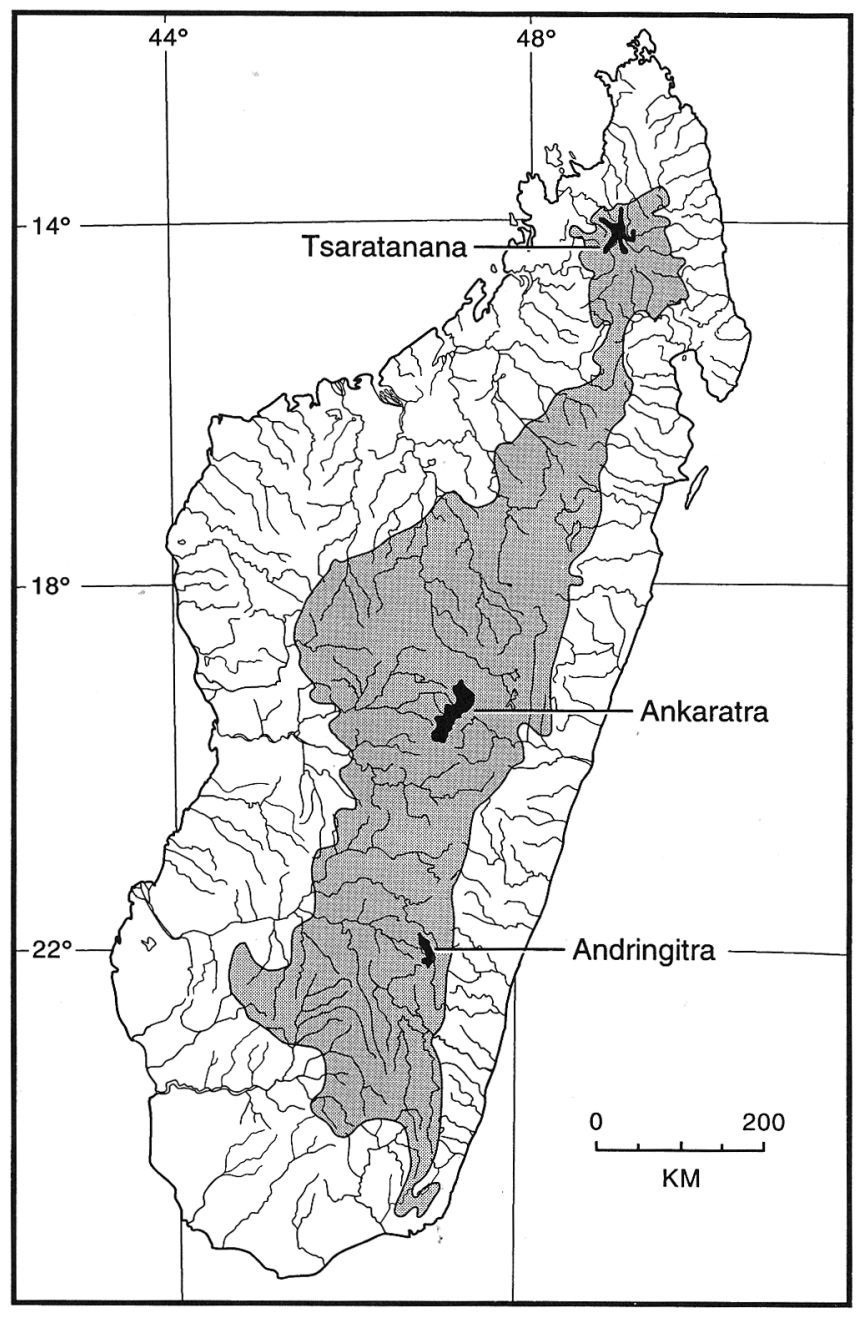

Figure 1. The bigh plateau of Madagascar (shaded > 800 m elevation) and associated major massifs (black $>2000 \mathrm{~m}$ ). In Madagascar montane habitats above $1500 \mathrm{~m}$ elevation are confined to the bigh plateau.

(Perrier de la Bâthie 1936; Jenkins 1987), suggesting insufficient time since the creation of the prairies for the evolution of endemic species or subspecies.

The primary montane vegetation of the three highest massifs in Madagascar-Tsaratanana (2876 m), Ankaratra (2642 m), and Andringitra (2658 m)-is also thought to be badly degraded or destroyed because of burning by humans (Jenkins 1987; Nicoll \& Langrand 1989). Four primary montane (above $1500 \mathrm{~m}$ ) vegetation types are recognized currently: moist montane (moss) forest in less exposed areas; sclerophyllous (lichen) montane forest; montane heathland (bushland) in isolated patches on exposed ridges above $2000 \mathrm{~m}$; and rupicolous shrubland restricted to rocky outcrops (Perrier de la Bâthie 1927; White 1983). No primary heathland survives at Ankaratra and Tsaratanana; both massifs have been burned frequently during this century (Perrier de la Bâthie 1927; Humbert 1928; Guillaumet 1984). The fre- quency of fires at Andringitra (Jenkins 1987) and our personal observations suggest that almost all extant heathland at this site is also secondary.

The large areas of extant, secondary montane heathland, typically dominated by Pbilippia and grasses, are usually interpreted as anthropogenic habitats (produced by human burning of sclerophyllous forest or primary heathland) that are faunistically depauperate (Humbert 1927, 1928; Perrier de la Bâthie 1927). Therefore, these secondary heathlands are considered analogous to the pseudo-steppe prairies of the high plateau. In montane regions, however, there is evidence of natural wildfires occurring throughout the Holocene (Burney 1987a), which in addition to recent reports of lightning-caused fires (Jenkins 1987), suggests that secondary heathland is a natural, post-fire successional stage.

The Madagascan herpetofauna, with about 550 total endemic species (Raxworthy \& Nussbaum, unpublished data), represents about $65 \%$ of the endemic vertebrate species of Madagascar. This diverse group is well-suited for analyzing patterns of endemism within Madagascar because herpetofaunal species typically have restricted elevational and regional distributions, reflecting considerable habitat specialization (Raxworthy \& Nussbaum 1994, 1995). None of these 550 island endemic species is restricted to obvious anthropogenic habitats (such as agricultural or urban areas), despite the widespread occurrence of anthropogenic habitats throughout Madagascar. Herpetofaunal species that occur in anthropogenic habitats appear to have invaded from adjacent natural habitats and probably have broad ecological tolerances.

Based on this observation, we predict that if secondary montane heathland and high plateau prairie are anthropogenic, with no history prior to human colonization, there should be no herpetofaunal species endemic to just these habitats. To test the working hypothesis that these habitats are of anthropogenic origin, we measured levels of herpetofaunal (amphibian and reptile) endemicity in primary forest, secondary heathland, and prairie habitats.

\section{Methods}

Surveys were completed during the rainy seasons of 1993 (January-March, October-December) when most species are breeding and activity is at its highest. Field techniques used to sample animals were (1) opportunistic day and night searching; (2) refuge examination (under and in fallen logs and rotten tree stumps, under bark, under rocks, in leaf litter, in root-mat and soil, and in leaf axils of screw palms of the genus Pandanus); and (3) pitfall trapping with drift fences. Opportunistic searching and refuge examination were done throughout the full elevational range of habitats available. Night 
Table 1. Habitat distribution of species of amphibians and reptiles endemic to the high plateau (800-1500 m elevation)."

\begin{tabular}{|c|c|c|c|c|c|}
\hline \multirow[b]{2}{*}{ Species $^{b}$} & \multicolumn{5}{|c|}{ Higb plateau babitat } \\
\hline & Prairie & Forest & Wetland & Rupicolous & Unknown \\
\hline \multicolumn{6}{|l|}{$\begin{array}{l}\text { Amphibia } \\
\text { Hyperoliidae }\end{array}$} \\
\hline $\begin{array}{l}\text { Heterixalus rutenbergi } \text { Boettger } 1881 \\
\text { Microhylidae }\end{array}$ & $+^{c}$ & & + & & \\
\hline Pletbodontobyla A & & + & & & \\
\hline $\begin{array}{l}\text { Scaphiopbryne gottlebet Busse \& Böhme } 1992 \\
\text { Mantellidae }\end{array}$ & & & & & $+d$ \\
\hline Mantella aurantiaca Mocquard 1900 & & + & & & \\
\hline Mantella cowani Boulenger 1882 & & & & & $t^{e}$ \\
\hline $\begin{array}{l}\text { Mantidactylus ambobimitombi Boulenger } 1919 \\
\text { Rhacophoridae }\end{array}$ & & + & & & \\
\hline Boophis tdae Steindachner 1867 & & $+f$ & & & \\
\hline Boopbis goudoti Tschudi 1838 & & + & & & \\
\hline Boopbis mandraka Blommers-Schlösser 1979 & & + & & & \\
\hline Boophis rbodoscelis Boulenger 1882 & & $+f$ & & & \\
\hline Boophis erythrodactylus Guibé 1953 & & + & & & \\
\hline Boophis billenit Blommers-Schlösser 1979 & & $+^{f}$ & & & \\
\hline Boophis A & & + & & & \\
\hline Boophis B & & + & & & \\
\hline Boophis C & & + & & & \\
\hline $\begin{array}{l}\text { Reptilia } \\
\text { Opluridae }\end{array}$ & & & & & \\
\hline $\begin{array}{l}\text { Oplurus grandidieri Mocquard } 1900 \\
\text { Chamaeleonidae }\end{array}$ & & & & +8 & \\
\hline Brookesia thieli Brygoo and Domergue 1969 & & + & & & \\
\hline Brookesia therezieni Brygoo and Domergue 1970 & & + & & & \\
\hline Calumma brevicornis tsarafidy Brygoo \& Domergue 1970 & & $+b$ & & & \\
\hline Calumma fallax Mocquard 1900 & & + & & & \\
\hline Calumma globifer Günther 1879 & & $+^{i}$ & & & \\
\hline Calumma malthe Günther 1879 & & + & & & \\
\hline $\begin{array}{r}\text { Calumma A } \\
\text { Cordylidae }\end{array}$ & & + & & & \\
\hline Zonosaurus ornatus Gray 1845 & + & & + & & \\
\hline $\begin{array}{r}\text { Zonosaurus A } \\
\text { Typhlopidae }\end{array}$ & & + & & & \\
\hline $\begin{array}{l}\text { Typblops domerguei Roux-Estève } 1980 \\
\text { Colubridae }\end{array}$ & & + & & & \\
\hline Brygophis coulangesi Domergue 1988 & & $+^{j}$ & & & \\
\hline Geodipsas vinckei Domergue 1988 & & $+\prime$ & & & \\
\hline Geodipsas A & & + & & & \\
\hline Liopbolidopbis pinguts Parker 1925 & & & + & & \\
\hline Ltopbolidophis sexlineatus Günther 1882 & & & + & & \\
\hline Pseudoxyrbopus ankafinaensis Raxworthy and Nussbaum 1994 & & + & & & \\
\hline
\end{tabular}

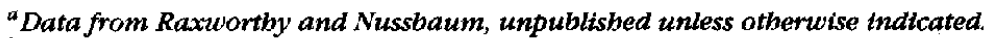

${ }^{b}$ Taxa not assigned specific names were constdered undescribed and are the subject of ongoing taxonomic studies to be publisbed elsewbere.

${ }^{c}$ Blommers-Schlösser (1982).

${ }^{d}$ Busse \& Böbme (1992).

'Boulenger (1882).

${ }^{f}$ Blommers-Scblösser (1979).

$s_{\text {Blanc (1977). }}$.

${ }^{b}$ Brygoo (1971).

${ }^{i}$ Seguier-Guis (1988).

${ }^{\prime}$ Domergue (1988).

searches were made using headlights. Pitfall trapping proceeded as described by Raxworthy and Nussbaum (1994). Date, time, longitude and latitude, altitude, habitat, and microhabitat were recorded at the time of capture of each individual.

Voucher specimens were fixed in $10 \%$ buffered forma- lin and later transferred to alcohol. Liver and muscle were removed from representatives of almost all species and frozen in liquid nitrogen for genetic studies. Representative live individuals of most species were photographed to record color, which fades in preservative. Voucher specimens were deposited either in the Museum 
Table 2. Habitat and elevational distribution of montane endemic ( $>1500 \mathrm{~m}$ elevation) species of amphibians and reptiles.

\begin{tabular}{|c|c|c|c|c|c|c|}
\hline \multirow[b]{2}{*}{ Species $^{b}$} & \multicolumn{3}{|c|}{ Massif ${ }^{a}$} & \multirow{2}{*}{$\begin{array}{l}\text { Massif } \\
\text { endemic }\end{array}$} & \multicolumn{2}{|c|}{ Elevation $(m)$} \\
\hline & Tsaratanana & Ankaratra & Andringitra & & $\min$ & $\max$ \\
\hline \multicolumn{7}{|l|}{ Amphibia } \\
\hline Anodontbyla montana Angel 1925 & & & $\mathbf{F}, \mathbf{H}$ & + & 1700 & 2300 \\
\hline Platypelis tsaratananaensis Guibé 1974 & $\mathbf{F}$ & & & + & 2350 & 2350 \\
\hline Platypelis A & $\mathbf{F}$ & & & + & 2350 & 2350 \\
\hline Pletbodontobyla guentberpetersi Guibé 1974 & $\mathbf{F}$ & & & + & 2300 & 2300 \\
\hline Pletbodontobyla tuberata Millot and Guibé 1954 & & F, H & & + & 1700 & 2550 \\
\hline Pletbodontobyla A & $\mathbf{H}$ & & & + & 2700 & 2700 \\
\hline Plethodontobyla B & $\mathbf{F}$ & & & + & 2050 & 2050 \\
\hline Pletbodontobyla C & $\mathbf{F}$ & & & + & 2050 & 2050 \\
\hline Scapbiopbryne A & $\mathbf{F}$ & & & + & 1900 & 1900 \\
\hline $\begin{array}{l}\text { Stumpffia A } \\
\quad \text { Mantellidae }\end{array}$ & $\mathbf{F}$ & & & + & 2050 & 2050 \\
\hline Mantidactylus aerumnalis Peracca 1893 & & F & $\mathbf{H}$ & & 1700 & 2150 \\
\hline Mantidactylus alutus Peracca 1893 & & F, H & & & 1700 & 2500 \\
\hline $\begin{array}{l}\text { Mantidactylus domerguei Guibé } 1974 \\
\text { Rhacophoridae }\end{array}$ & & $\mathrm{F}$ & $\mathrm{F}, \mathrm{H}^{c}$ & & $1500^{d}$ & 2150 \\
\hline $\begin{array}{l}\text { Boopbis microtympanum Boettger } 1881 \\
\text { Reptilia }\end{array}$ & & $\mathbf{H}$ & $\mathbf{H}$ & & 1850 & 2550 \\
\hline Gekkonidae & & & & & & \\
\hline Lygodactylus montanus Pasteur 1964 & & & $\mathbf{R}$ & + & 2000 & 2250 \\
\hline Millotisaurus mirabilis Pasteur 1962 & & $\mathbf{R}$ & & + & 2400 & 2640 \\
\hline Pbelsuma barbouri Loveridge 1942 & & $\mathbf{R}$ & $\mathbf{R}$ & & 1600 & 2640 \\
\hline $\begin{array}{l}\text { Pbelsuma lineata punctulata Mertens } 1970 \\
\text { Chamaeleonidae }\end{array}$ & $\mathbf{R}$ & & & + & 2700 & 2870 \\
\hline $\begin{array}{l}\text { Brookesia lolontany } \\
\text { Raxworthy and Nussbaum } 1995\end{array}$ & F & . & & + & 1650 & 2050 \\
\hline $\begin{array}{l}\text { Calumma brevicornis billeniusi } \\
\text { Brygoo, Blanc, and Domergue } 1973\end{array}$ & & $\mathbf{F}, \mathbf{H}$ & $\mathbf{F}, \mathbf{H}$ & & 1550 & 2550 \\
\hline Calumma guibe Hillenius 1959 & $\mathbf{F}$ & & & + & 1600 & 2100 \\
\hline $\begin{array}{l}\text { Calumma tsaratananaensis } \\
\text { Brygoo, Blanc, and Domergue } 1969\end{array}$ & $\mathbf{H}$ & & & + & 2700 & 2800 \\
\hline Calumma A & $\mathbf{F}$ & & & + & 2550 & 2550 \\
\hline Calumma B & F & & & + & 1630 & 2350 \\
\hline $\begin{array}{l}\text { Furcifer campani Grandidier } 1872 \\
\text { Scincidae }\end{array}$ & & $\mathbf{H}$ & $\mathbf{H}$ & & 1850 & 2500 \\
\hline Ampbiglossus tsaratananaensis Brygoo 1981 & $\mathbf{F}, \mathbf{H}$ & & & + & 2050 & $2870^{e}$ \\
\hline Ampbiglossus A & & $\mathbf{F}, \mathrm{H}$ & $\mathbf{H}$ & & 1700 & 2640 \\
\hline Mabuya boettgeri Boulenger 1887 & & $\mathbf{H}$ & $\mathbf{H}$ & & 1600 & 2400 \\
\hline $\begin{array}{l}\text { Mabuya madagascariensis Mocquard } 1908 \\
\text { Colubridae }\end{array}$ & & $\mathbf{H}$ & & & 1650 & 2400 \\
\hline Geodipsas B & $\mathbf{F}$ & & & + & 1620 & 2050 \\
\hline
\end{tabular}

${ }^{a} F$, montane moist and sclerophyllous forest; $H$, secondary beatbland; $R$, rupicolous babitats.

${ }^{b}$ Taxa not assigned spectfic names were considered undescribed and are the subject of ongoing taxonomic studtes to be publtshed elsewhere.

'Millot \& Guibé (1950).

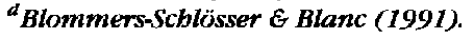

Brygoo (1981).

of Zoology, University of Michigan, or in the collections of the Service de Zoologie, Université d'Antananarivo.

A list of amphibians and reptiles endemic to the High Plateau and their habitat associations was compiled from our field work and from the literature (cited in Table 1). These data are based on studies made in the regions of Ambatondrazaka, Ambatolampy, Ambositra, Ambohitantely, Andringitra, Antananarivo, Isalo, Mandraka, Mantady, Perinet, Ranomafana, Tsarafidy, and Zahamena. Co- ordinates and further information of these sites are given by the U.S. Department of the Interior (1955) and by Nicoll and Langrand (1989).

The three montane systems surveyed were Ankaratra, 10-24 February, $19^{\circ} 21^{\prime} \mathrm{S}, 47^{\circ} 18^{\prime} \mathrm{E}$; $19^{\circ} 22^{\prime} \mathrm{S}, 47^{\circ} 19^{\prime} \mathrm{E}$; Tsaratanana, 18 March-4 April, $14^{\circ} 09^{\prime} \mathrm{S}, 48^{\circ} 58^{\prime} \mathrm{E} ; 14^{\circ} 06^{\prime} \mathrm{S}$, $48^{\circ} 59^{\prime} \mathrm{E} ; 14^{\circ} 11^{\prime} \mathrm{S}, 48^{\circ} 57^{\prime} \mathrm{E}$; and Andringitra, 8-17 December, $22^{\circ} 12^{\prime} \mathrm{S}, 46^{\circ} 58^{\prime} \mathrm{E} ; 22^{\circ} 10^{\prime} \mathrm{S}, 46^{\circ} 56^{\prime} \mathrm{E}$. Montane habitats were classified and identified as follows: (1) 


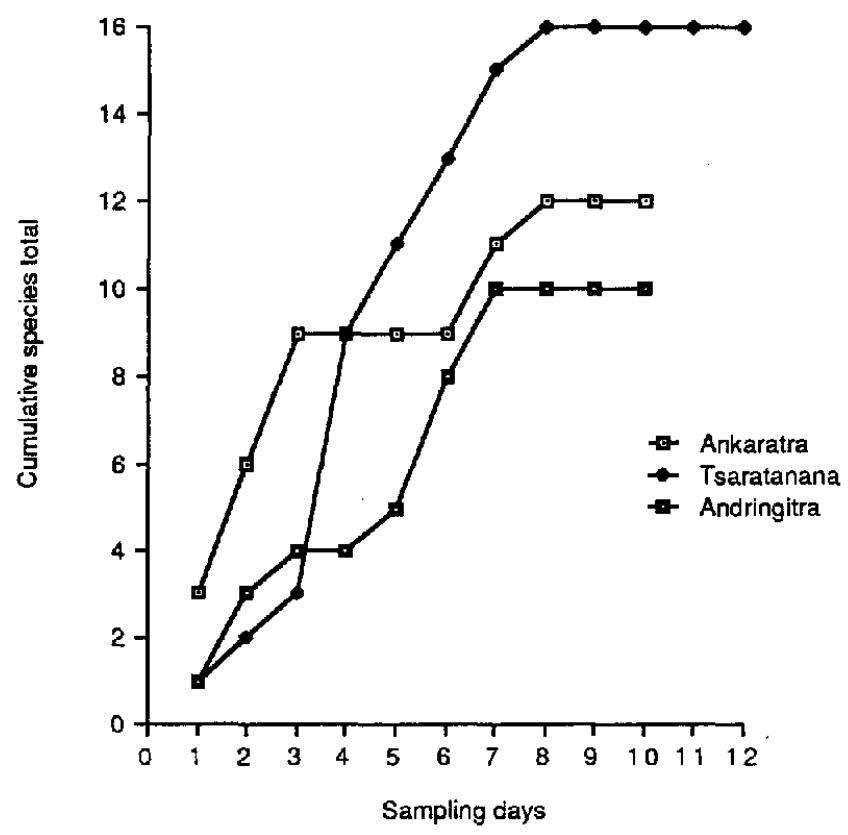

Figure 2. Accumulation curves illustrating the rate of discovery of new species of amphibians and reptiles at eacb montane site.

montane moist and sclerophyllous forest, trees forming a continuous canopy; (2) secondary heathland, vegetation dominated by ericoid shrubs and grasses with evidence of former burning (blackened tree trunks, stems, or roots); (3) rupicolous habitats, areas of rock surface and crevices. Montane moist forest was not distinguished from sclerophyllous forest because the two types proved to intergrade over broad areas.

\section{Results}

Of the herpetofauna surveyed, nine species of amphibians and seven species of reptiles appear to be undescribed taxa. This reflects the general lack of herpetological survey work that has been conducted in the interior of Madagascar. These new species are in the process of being described and in all cases are represented by voucher specimens. Because these new species represent such a sizeable fraction of the surveyed herpetofauna, we have chosen to include them in this analysis.

We identified 32 species of amphibians and reptiles as high plateau endemics (restricted to elevations between 800 and $1500 \mathrm{~m}$ on the high plateau). These endemics and their habitat types are listed in Table 1. Of these, 25 (78\%) are restricted to forest habitat. Just two species (6\%) occupy prairie, and neither is confined to this habitat. The complete absence of endemism in the high plateau prairie supports the current belief that this habitat is artificial and of recent origin.
Our surveys of the three major massifs (Andringitra, Ankaratra, Tsaratanana) yielded 30 amphibians and reptiles restricted to $1500 \mathrm{~m}$ elevation or higher (Table 2). No additional species were found during the final 3-5 survey days at each site (Fig. 2), which indicates that these species lists are nearly complete. Four geckos (Gekkonidae) are restricted to montane rupicolous habitats. All other montane species (Microhylidae, Mantellidae, Rhacophoridae, Chamaeleonidae, Scincidae, and Colubridae) occur only in heathland and/or forest.

The herpetofaunal species diversity for secondary montane heathland is eight species at Andringitra, eight at Ankaratra, and three at Tsaratanana. Five species are restricted to secondary montane heathland at Andringitra, four at Ankaratra, and two at Tsaratanana. At Tsaratanana, 12 species are restricted to moist or sclerophyllous forest, compared to just two at Ankaratra and none at Andringitra (Table 3). Secondary heathland is occupied by $54 \%$ of the nonrupicolous montane herpetofauna (all three massifs combined), and $23 \%$ of the species are found only in this montane secondary habitat. The significant percentage of montane endemic species restricted to secondary heathland contrasts sharply with the results for the high plateau prairie, where no endemic species were identified. We therefore reject the hypothesis that montane secondary heathland is artificial and faunistically depauperate.

\section{Discussion}

The absence of endemic amphibians and reptiles in the high plateau prairie strongly suggests that the modern prairie is recent and artificial, and that the original vegetation (and its endemic herpetofauna) has been lost. Claims that the original vegetation was extremely susceptible to fire and that it was therefore destroyed by the very first human-set fires (Morat 1973) cannot be supported because wildfires were common the high plateau throughout the Holocene (Burney 1987a, 1987b). It is also unlikely that such a large area of natural vegetation, 22,350-36,000 $\mathrm{km}^{2}$ (Jenkins 1987), was destroyed by clearing, because the original human population must have been small (MacPhee et al. 1985). Grazing by introduced domestic bovids also has been proposed to explain the destruction of the natural vegetation of the

Table 3. Number of montane endemic ( $>1500 \mathrm{~m}$ elevation) herpetological species in different habitats.

\begin{tabular}{lcccc} 
& \multicolumn{4}{c}{ Habitat } \\
\cline { 2 - 5 } Massif & Rupicolous & Forest & Heatbland & $\begin{array}{c}\text { Forest and } \\
\text { beatbland }\end{array}$ \\
\hline Tsaratanana & 1 & 12 & 2 & 1 \\
Ankaratra & 1 & 2 & 4 & 4 \\
Andringitra & 2 & 0 & 5 & 3 \\
\hline
\end{tabular}


high plateau (Dewar 1984). We suspect that the modern practice of yearly burning for improved grazing (widespread throughout the high plateau) originated when pastoralists first settled in Madagascar, and that regular, repeated burning, rather than grazing per se, ultimately destroyed the original high plateau vegetation. Unlike prairie, the montane habitats have not been frequently burned; therefore, their natural, post-fire successional stages have not yet been destroyed.

We propose the following revised montane vegetational model for Madagascar. Prior to human colonization, a mosaic of sclerophyllous forest and heathland was maintained by natural wildfires within each of the major massifs of Madagascar. Secondary heathland developed as a post-fire successional stage leading to a climax of sclerophyllous forest, except on the most exposed ridges, plateaus, and summits, where heathland was the climax vegetation. The rupicolous montane habitats, largely protected from fire, remained stable.

At the northern massif, Tsaratanana, $75 \%$ of the montane herpetofauna is restricted to moist or sclerophyllous forest, a much higher percentage than on the two central massifs, Ankaratra and Andringitra, with just 17\% and $0 \%$ respectively. This contrast may result from differences in the size of the montane forest refugia that existed at each massif during glacial periods of the Pleistocene. In East Africa, glacial periods of the Pleistocene had much drier climates, which caused the montane forests to contract during these periods (Hamilton 1982). Current rainfall is considerably higher at Tsaratanana (mean monthly rainfall $200-250 \mathrm{~mm}$ ) than at the two central massifs (mean monthly rainfall $100-150 \mathrm{~mm}$ ) (Donque 1972). If rainfall was also higher at Tsaratanana during glacial periods than on the central massifs, then montane forest would have been much more extensive at Tsaratanana than Ankaratra or Andringitra. The larger (and probably more stable) montane forest refuge at Tsaratanana would, therefore, be expected to have a greater diversity of montane forest specialists than either Ankaratra or Andringitra.

The secondary montane habitats in Madagascar are obviously not depauperate of endemic vertebrates, a result that has important implications for conservation. Despite frequent burning at Ankaratra and Andringitra, the secondary heathlands of both massifs still have diverse herpetofaunas. The montane vegetation of Tsaratanana, frequently reported to have been completely destroyed by fire (Guillaumet 1984; Jenkins 1987; Nicoll \& Iangrand 1989), also has a secondary heathland that supports an endemic herpetofauna. The sclerophyllous forest at Tsaratanana, claimed in 1924 to have been completely burned above $2200 \mathrm{~m}$ elevation (Perrier de la Bâthie 1927), has actually regenerated or survived in some areas to an elevation of $2600 \mathrm{~m}$ (Raxworthy, personal observation).

The widely held view that the Madagascan montane habitats have been destroyed or degraded has been largely responsible for the lack of research and conservation programs in these regions. At Tsaratanana (the most diverse massif with probably the highest degree of local endemicity of any site in Madagascar) our survey was the first scientific study made at the summit in almost 30 years, and there are no conservation programs currently active within the Tsaratanana Reserve. Although conservation programs have recently been established at Andringitra and Ankaratra, the lack of research on the high-elevation habitats is preventing their effective management.

Our results suggest that montane communities in Madagascar may be more resistant to fire than currently realized. Post-fire secondary heathland is a valuable habitat with a diverse endemic fauna. If protected from further burning or cattle grazing, it may develop into climax sclerophyllous forest. This offers the possibility that careful management of heathland could establish new dispersal corridors between montane forest blocks. This conclusion, if confirmed, offers new challenges and opportunities for conservation management in Madagascar.

\section{Acknowledgments}

We thank $H$. Wright and $R$. Burke for comments on an earlier draft of this paper. We are greatly indebted to Jean Baptiste Ramanamanjato, Achille Raselimanana, and Anglien and Angeluc Razafimanantsoa for help in the field. This research was made possible through the cooperation of the Malagasy Ministère de l'Enseignement Supérieur, the Ministère de la Production Animale et des Eaux et Forêt, and the Ministère de la Recherche Scientifique et Technologie pour le Developpement. This research was supported in part by a grant (BSR 90-24505) from the National Science Foundation. Logistic support at Andringitra was provided by the World Wide Fund for Nature.

\section{Literature Cited}

Blanc, C. P. 1977. Reptiles. Sauriens. Iguanidae. Faune de Madagascar 45:1-200.

Blommers-Schlösser, R. M. A. 1979. Biosystematics of the Malagasy frogs. II. The genus Boopbis (Rhacophoridae). Bijdragen Dierkunde 49:261-312.

Blommers-Schlösser, R. M. A. 1982 . Observations on the Malagasy genus Hetertxalus Laurent, 1944 (Hyperoliidae). Beaufortia 32:1-11.

Blommers-Schlösser, R. M. A., and C. P. Blanc. 1991. Amphibiens (premiére partie). Faune de Madagascar 75:1-400.

Boulenger, G. A. 1882. Catalogue of the Batrachia Salientia s. Caudata in the collection of the British Museum. British Museum, London.

Brygoo, E. R. 1971. Reptiles Sauriens Chamaeleonidae, le genre Chamaeleo. Faune de Madagascar 33:1-318.

Brygoo, E. R. 1981. Systématique des lézards scincidés de la région malgache. VI. Deux scincidés nouveaux. Bulletin de la Musée National de Histoire naturelle, Paris, 4th Series, Section A 3:261-268.

Burney, D. A. 1987a. Pre-settlement vegetation changes at Lake Tritrivakely, Madagascar. Palaeoecology of Africa 18:357-381. 
Burney, D. A. $1987 b$. Late Quaternary stratigraphic charcoal records from Madagascar. Quaternary Research 28:274-280.

Busse, K., and W. Böhme. 1992. Two remarkable frog discoveries of the genera Mantella (Ranidae: Mantellinae) and Scapbiopbryne (Microhylidae, Scaphiophryninae) from the west coast of Madagascar. Revue Francaise d'Aquariologie, Herpétologie 19:57-64.

Dewar, R. E. 1984. Extinctions in Madagascar. Pages 574-593 in P. S. Martin and R. G. Klein, editors. Quaternary extinctions: a prehistoric revolution. University of Arizona Press, Tucson.

Domergue, C. A. 1988. Notes sur les serpents de la région Malgache. VIII. Colubridae nouveaux. Bulletin de la Musée National de Histoire naturelle, Paris, 4th Series, Section A 10:135-146.

Donque, G. 1972. The Climatology of Madagascar. Pages 87-144 in R. Battistini and G. Richard-Vindard, editors. Biogeography and ecology in Madagascar. Junk, The Hague.

Guillaumet, J. L. 1984. The vegetation: an extraordinary diversity. Pages 27-54 in A. Jolly, P. Oberlé, and R. Albignac, editors. Key environments: Madagascar. Pergamon, Oxford, United Kingdom.

Hamilton, A. C. 1982. Environmental history of East Africa. Academic Press, London.

Humbert, H. 1927. La destruction d'une flore Insulaire par le feu. Principaux aspects de la végétation à Madagascar. Mémoires. de l'Académie Malgache 5:1-78.

Humbert, H. 1928. Végétation des hautes montagnes de Madagascar. Mémoires de la Société de Biogeographie 2:195-220.

Jenkins, M. D. 1987. Madagascar, an environmental profile. World Conservation Union, Gland, Switzerland

Koechlin, J. 1972. Flora and vegetation of Madagascar. Pages 145-190 in R. Battistini and G. Richard-Vindard, editors. Biogeography and ecology in Madagascar. Junk, The Hague.

MacPhee, R. D. E., D. A. Burney, and N. A. Wells. 1985. Early Holocene chronology and environment of Ampasambazimba, a Malagasy subfossil lemur site. International Journal of Primatology 6:463-489.

Millot J., and J. Guibé. 1950. Les Batraciens du Nord de l'Andringitra (Madagascar). Mémoires de l'Institute Scientifique de Madagascar Series A 4:179-206.

Morat, P. 1973. Les savanes de l'Ouest de Madagascar. Mémoires de I'ORSTOM 68:191-193.

Nicoll, N. E., and O. Langrand. 1989. Madagascar: Revue de la Conservation et des Aires Protégées. Fonds Mondial pour la Nature, Gland, Switzerland.

Perrier de la Bâthie, H. 1921. La végétation Malgache. Annales du Musée Colonial de Marseille, 3rd Series 9:1-29.

Perrier de la Bâthie, H. 1927. Le Tsaratanana, l'Ankaratra et l'Andringitra. Mémoires de l'Académie Malgache 3:1-52.

Perrier de la Bâthie, H. 1936. Biogéographie des Plantes de Madagascar. Société d'Editions Géographiques, Maritimes, et Coloniales, Paris.

Raxworthy, C. J., and R. A. Nussbaum. 1994. A rainforest survey of amphibians, reptiles and small mammals at Montagne d'Ambre, Madagascar. Biological Conservation 69:65-74.

Raxworthy, C. J., and R. A. Nussbaum. 1995. Systematics, speciation, and biogeography of the dwarf chameleons Brookesia Gray (Reptilia; Sauria; Chamaeleontidae) of northern Madagascar. Journal of Zoology, London 235:525-558.

Seguier-Guís, M. 1988. Contribution à l'inventoire des vertebres de la Forêt d'Ambohitantely (Tampoketsa d'Ankazobe). Thesis. Université de Madagascar, Antananarivo.

U.S. Department of the Interior. 1955. Gazetteer 2. Madagascar, Réunion and the Comoro Islands. Office of Geography (Department of the Interior), Washington, D. C.

White, F. 1983. The vegetation of Africa. United Nations Educational, Social, and Cultural Organization, Paris. 